\title{
Cross-sectional earnings risk and occupational sorting: The role of risk attitudes
}

Citation for published version (APA):

Bonin, H., Dohmen, T. J., Falk, A., Huffman, D., \& Sunde, U. (2007). Cross-sectional earnings risk and occupational sorting: The role of risk attitudes. Labour Economics, 14(6), 926-937. https://doi.org/10.1016/j.labeco.2007.06.007

Document status and date:

Published: 01/01/2007

DOI:

10.1016/j.labeco.2007.06.007

Document Version:

Publisher's PDF, also known as Version of record

\section{Please check the document version of this publication:}

- A submitted manuscript is the version of the article upon submission and before peer-review. There can be important differences between the submitted version and the official published version of record.

People interested in the research are advised to contact the author for the final version of the publication, or visit the DOI to the publisher's website.

- The final author version and the galley proof are versions of the publication after peer review.

- The final published version features the final layout of the paper including the volume, issue and page numbers.

Link to publication

\footnotetext{
General rights rights.

- You may freely distribute the URL identifying the publication in the public portal. please follow below link for the End User Agreement:

www.umlib.nl/taverne-license

Take down policy

If you believe that this document breaches copyright please contact us at:

repository@maastrichtuniversity.nl

providing details and we will investigate your claim.
}

Copyright and moral rights for the publications made accessible in the public portal are retained by the authors and/or other copyright owners and it is a condition of accessing publications that users recognise and abide by the legal requirements associated with these

- Users may download and print one copy of any publication from the public portal for the purpose of private study or research.

- You may not further distribute the material or use it for any profit-making activity or commercial gain

If the publication is distributed under the terms of Article $25 \mathrm{fa}$ of the Dutch Copyright Act, indicated by the "Taverne" license above, 


\title{
Cross-sectional earnings risk and occupational sorting: The role of risk attitudes
}

\author{
Holger Bonin, Thomas Dohmen *, Armin Falk, \\ David Huffman, Uwe Sunde
}

Received 16 January 2006; received in revised form 24 May 2007; accepted 5 June 2007

Available online 16 June 2007

\begin{abstract}
This paper investigates to what extent individuals' risk preferences are correlated with the cross-sectional earnings risk of their occupation. We exploit data from the German Socio-Economic Panel, which contains a direct survey question about willingness to take risks that has been shown to be a behaviorally valid measure of risk aversion. As a measure of earnings risk, we use the cross-sectional variation in earnings that is left unexplained by human capital variables in Mincerian wage regressions. Our evidence shows that individuals with low willingness to take risks are more likely to work in occupations with low earnings risk. This pattern is found regardless of the level of occupation categories, region, gender and labor market experience.
\end{abstract}

(C) 2007 Elsevier B.V. All rights reserved.

JEL classification: J24; J31; D01; D81

Keywords: Occupational choice; Sorting; Risk preferences; SOEP; Earnings risk

\section{Introduction}

Certain occupations are riskier than others. Occupations differ in terms of risk of injury, fatality, and other health hazards, but also in terms of economic risks, such as earnings risk. Therefore, occupational choice is likely to depend on an individual's attitude towards risk. At the same time, occupational choice is strongly interrelated with educational choice. This is particularly true in economies with strict occupation-specific education requirements, such as in Germany with its dual education system. In the German system, educational choices or the choice of an apprenticeship occupation largely predetermines the subsequent career (Fitzenberger and

\footnotetext{
* Corresponding author. IZA, P.O. Box 7240, D-53072 Bonn, Germany. Tel.: +49 2283894 204; fax: +49 2283894180. E-mail address: dohmen@iza.org (T. Dohmen).
} 
Kunze, 2005). Thus risk attitudes might be expected to affect the joint decision to sort into a particular occupation, and hence to follow a specific education track.

Despite the large literature on compensating wage differentials for heterogeneous, risk averse agents, this evidence is mostly confined to indirect evidence that agents who are more willing to exchange wages for risk choose to work in riskier occupations. ${ }^{1}$ To our knowledge, there exists almost no direct evidence about how individuals that differ in their risk attitudes are sorted into occupations with different earnings risk. The reason is that, while risk attitudes play a crucial role in education and occupation choices, they are difficult to measure in practice. Among the few studies in this area, DeLeire and Levy (2004) suggest family structure as a proxy for risk preferences. They show that primary caregivers, who are arguably less willing to take risks, tend to work in occupations with lower risk of death. Cramer et al. (2002) use answers to a hypothetical lottery question to measure risk attitudes, and establish the relevance of risk attitudes for choosing self-employment, which is considered a more risky occupation than being an employee. Ekelund et al. (2005) find similar results on risk attitudes and self-employment, using a psychometric measure of harm avoidance as an indicator of propensity to take risks.

This paper contributes to this literature by presenting the first evidence on the correlation between cross-sectional earnings risk and individual risk attitudes, using a new and direct measure of individual willingness to take risks that was elicited in the survey of the German Socio-Economic Panel (SOEP). This subjective measure has been shown to be a valid predictor of actual risky behavior in an experimental validation study by Dohmen et al. (2005). As a direct measure of economic risk associated with a specific occupation, we use the occupation-specific variance in earnings that cannot be explained by returns to human capital in Mincerian wage regressions. ${ }^{2}$ By correlating individuals' risk attitudes with the earnings risk in their occupation, we investigate whether one indeed observes that relatively more risk averse individuals are sorted into occupations with lower earnings variance, as theory would predict. In contrast, previous work focused on the choice between two occupational alternatives (dependent employment and selfemployment) that are implicitly assumed to differ with respect to some sort of risk exposure (see, for example, Ekelund et al., 2005).

Using our two direct measures we find a positive and highly significant correlation between occupational risk and individual risk attitudes, even when controlling for individual characteristics and wages. In other words we find strong support for the hypothesis that individuals who are more inclined to take risks are sorted into occupations that are characterized by greater variance in earnings. Moreover, we find that this pattern is robust with respect to the level of occupation categories, region, gender and labor market experience.

Our findings have important implications. The results indicate that labor markets are capable of allocating risks relatively efficiently. Given the complexity of the decisions involved in choosing an appropriate occupation, the costs of acquiring the necessary information, and the presence of constraints on mobility, it is striking that decentralized decision making in markets generates selection patterns where risk tolerant workers are selected into relatively risky occupations while relatively risk averse subjects are sorted into less risky occupations. Such

\footnotetext{
${ }^{1}$ There is a large body of evidence suggesting that agents are rewarded for taking occupation-specific risks (for an overview of the early literature, see Rosen, 1986). Among others, Thaler and Rosen (1976), Brown (1980) and Hwang et al. (1992) estimate a wage premium for jobs with higher fatality and accident risks. McGoldrick (1995) finds that women working in occupations with higher earnings variance tend to earn higher wages. Topel (1984), Murphy and Topel (1987) and Moore (1995) show that wages are higher in jobs suffering from higher unemployment and earnings risk. More recently, Hartog et al. (2003) observe that occupations with higher earnings variance pay higher wages.

2 This approach follows earlier contributions including McGoldrick (1995).
} 
occupational sorting also improves the allocative efficiency compared to a situation without such sorting. The results also suggest that pay structures in certain occupations attract individuals according to their risk attitudes. This kind of preference sorting, in turn, affects performance and outcomes in these occupations. ${ }^{3}$

The remainder of the paper is organized as follows. Section 2 discusses the measures of individual risk preferences and earnings risk underlying the analysis. Section 3 presents our core results, estimated on a sample of full-time employed men. The paper concludes with a discussion of the implications of our findings and topics for future research.

\section{Measures of Risk Attitudes and Earnings Risk}

In this section, we briefly describe our measure of risk preference, which derives from a survey question in the German Socio-Economic Panel (SOEP). We then derive our measure of earnings risk from the cross-sectional variation in earnings observed in the SOEP data.

\section{Measuring Risk Attitudes}

The SOEP is an annual panel survey of the German population representative for the resident German population aged 18 years and older. ${ }^{4}$ It collects information on a wide range of personal and household characteristics, including information about employment status, occupation, monthly gross earnings, average weekly working time and overtime, educational attainment, experience, and tenure. In the 2004 wave, which covers 22,019 individuals in 11,803 different households, the survey asked for the first time about an individual's risk attitudes. In particular, subjects where asked to express on an eleven-point scale their willingness to take risks in general, with zero indicating complete unwillingness to take risks, and ten indicating complete willingness to take risks. ${ }^{5}$

One could challenge the view that this self-reported measure of risk attitudes really reflects an underlying trait and is relevant for predicting behavior. There is, however, sufficient evidence to be confident that our measure does indeed reflect individuals' risk attitudes in a behaviorally relevant manner. The consistency and validity of the responses for actual behavior has been documented by Dohmen et al. (2005) in a field experiment with a subject pool that has characteristics comparable to those of the SOEP respondents. In particular, their study shows that the subjective measure of risk attitudes is highly correlated with risk attitudes elicited from lottery choices with real money at stake. The study also provides evidence that risk attitudes measured by the survey risk question better predict behavioral outcomes such as portfolio choice, smoking behavior, self-employment, mobility, and traffic offences than risk attitudes elicited from hypothetical lotteries. ${ }^{6}$

\footnotetext{
3 These findings are supported by evidence from a laboratory experiment conducted by Dohmen and Falk (2006) who find that relatively risk averse workers prefer fixed payments over variable payment schemes (e.g., piece-rates, tournament contracts, or revenue sharing contracts).

${ }^{4}$ For more details on the SOEP, see www.diw.de/english/.

5 The exact wording of the general risk question (in translation from German) is as follows: "How do you see yourself: Are you generally a person who is completely willing to take risks or do you try to avoid taking risks? Please tick a box on the scale, where the value 0 means: 'completely unwilling to take risks' and the value 10 means: 'completely willing to take risks'." German versions of all risk questions are available online, at www.diw.de/deutsch/sop/service/fragen/ personen/2004.pdf.

${ }^{6}$ Other evidence suggests that risk attitudes are stable over time (see, e.g., Barsky et al., 1997; Harrison et al., 2005). See also Ekelund et al. (2005) for a discussion of the stability of psychometric measures of risk attitudes.
} 


\section{Measuring Earnings Risk}

Our measure of earnings risk, which we use throughout the paper, is the cross-sectional variation in monthly wages that is not explained by observable differences in individuals' stocks of human capital. ${ }^{7}$ In particular, we estimate standard Mincer wage regressions (Mincer, 1974), including as explanatory variables measures of human capital such as years of schooling, potential experience and tenure as well as a full set of occupation dummies constructed using the International Standard Classification of Occupations (ISCO) code that is available in our data. ${ }^{8}$ We use the occupation-specific variance of the residuals as our measure of earnings risk.

The unexplained cross-sectional earnings variance is a relevant measure of earnings risk because it reflects the uncertainty that is associated with a particular occupation from an ex ante, outside perspective. From the perspective of an individual that contemplates which occupation to choose, conditional on her risk attitudes, this cross-sectional variance is a relevant measure for the risk associated with a particular occupation. To the extent that this measure of earnings risk is derived from a cross section of individual earnings, it also includes an element of variability of individual earnings over time. The latter is likely to be driven by idiosyncratic shocks and unobserved heterogeneity, and the result of past sequential choices and preferences of individuals, which might vary systematically across occupations. While capturing some of this variability, our cross sectional earnings risk measure is less affected by endogeneity problems resulting from sequential choices and preferences of individuals than a measure of individual earnings variability over time. Measuring earnings risk by the unexplained variance in cross-sectional earnings captures the earnings risk of an occupation from the perspective of an individual that has not yet sorted into this occupation. It therefore appears to be a sensible measure for the purpose of this study. $^{9}$

We restrict our sample to men between 25 and 55 years of age who are full-time employed. Since we also want to discard observations of full-time employed men whose wage information is extremely implausible, we drop observations of those in the top 1-percentile and bottom 1percentile of the wage distribution. ${ }^{10}$ We exclude part-time workers, apprentices, and workers in retirement, as well as those employed in military service or alternative civilian service from our sample. We also exclude the self-employed from our sample, because it is unclear whether the earnings definition is appropriate for the self-employed and whether earnings from selfemployment and dependent employment are comparable. Moreover, the reported earnings for self-employed are likely to be measured with more error. ${ }^{11}$ We focus on monthly earnings, but also conducted robustness checks using hourly wages.

\footnotetext{
${ }^{7}$ Within-occupation earnings variability that is driven by differences in human capital investments might affect educational choices but should not be perceived as earnings risk from the perspective of a person with a particular stock of human capital.

${ }^{8}$ To obtain reasonably large cell sizes, we group occupations on the broader 3-digit and 2-digit levels, using only the first three or the first two digits of the 4-digit ISCO code, respectively.

${ }^{9}$ Of course, this measure does not capture all components of the earnings risk associated with an occupation, like unemployment risk, or the risk of transitory shocks to earnings. Yet, conditional on becoming employed, our measure reflects earnings variability faced by an individual that knows about her observable characteristics, but does not know which match or job she will end up with.

${ }^{10}$ This means that we eliminate subjects with monthly wages for full-time employment of less than 155 Euros (1st percentile), or more than 10,000 Euros (99th percentile). The average monthly wage in our sample is 2,440.19 Euros with a standard deviation of 1,695.32 Euros.

${ }^{11}$ In fact, we replicated all our analysis including the self-employed, who make up only a small proportion of the sample. We found even stronger results on risk sorting.
} 
Table 1

Results of Mincerian Wage Regressions

\begin{tabular}{|c|c|c|c|c|}
\hline & \multicolumn{4}{|c|}{ Dependent Variable: $\log$ of Monthly Earnings } \\
\hline & (1) & (2) & (3) & (4) \\
\hline \multirow[t]{2}{*}{ Experience } & $0.094 * * *$ & $0.095 * * *$ & $0.093 * * *$ & $0.094 * * *$ \\
\hline & $(0.009)$ & $(0.009)$ & $(0.008)$ & $(0.008)$ \\
\hline \multirow[t]{2}{*}{ Experience $^{2} / 100$} & $-0.363 * * *$ & $-0.367 * * *$ & $-0.355^{* * *}$ & $-0.360 * * *$ \\
\hline & $(0.045)$ & $(0.044)$ & $(0.044)$ & $(0.044)$ \\
\hline \multirow[t]{2}{*}{ Experience $^{3} / 1000$} & $0.045 * * *$ & $0.046^{* * *}$ & $0.044 * * *$ & $0.045^{* * *}$ \\
\hline & $(0.007)$ & $(0.007)$ & $(0.007)$ & $(0.007)$ \\
\hline \multirow[t]{2}{*}{ Tenure } & $0.023 * * *$ & $0.023 * * *$ & $0.022 * * *$ & $0.022 * * *$ \\
\hline & $(0.002)$ & $(0.002)$ & $(0.002)$ & $(0.002)$ \\
\hline \multirow[t]{2}{*}{ Tenure $^{2} / 100$} & $-0.046^{* * *}$ & $-0.046^{* * *}$ & $-0.045^{* * *}$ & $-0.045 * * *$ \\
\hline & $(0.006)$ & $(0.006)$ & $(0.006)$ & $(0.006)$ \\
\hline \multirow[t]{2}{*}{ Years of Education } & $0.052 * * *$ & $0.052 * * *$ & $0.048 * * *$ & $0.049 * * *$ \\
\hline & $(0.003)$ & $(0.003)$ & $(0.003)$ & $(0.003)$ \\
\hline \multirow[t]{2}{*}{ East Germany } & $-0.277 * * *$ & $-0.279 * * *$ & $-0.274 * * *$ & $-0.276^{* * *}$ \\
\hline & $(0.013)$ & $(0.013)$ & $(0.013)$ & $(0.013)$ \\
\hline \multirow[t]{2}{*}{ Public Sector Employment } & $-0.087 * * *$ & $-0.086^{* * *}$ & $-0.095 * * *$ & $-0.093 * * *$ \\
\hline & $(0.015)$ & $(0.015)$ & $(0.017)$ & $(0.017)$ \\
\hline \multirow[t]{2}{*}{ General Risk Attitude } & & $0.012 * * *$ & & $0.013 * * *$ \\
\hline & & $(0.002)$ & & $(0.002)$ \\
\hline \multirow[t]{2}{*}{ Constant } & $6.435 * * *$ & $6.346^{* * *}$ & $6.486^{* * *}$ & $6.392 * * *$ \\
\hline & $(0.080)$ & $(0.082)$ & $(0.080)$ & $(0.082)$ \\
\hline \multicolumn{5}{|l|}{ Occupation Dummies } \\
\hline 2-Digit ISCO & Yes & Yes & No & No \\
\hline 3-Digit ISCO & No & No & Yes & Yes \\
\hline Observations & 3621 & 3612 & 3621 & 3612 \\
\hline R-squared & 0.55 & 0.55 & 0.57 & 0.58 \\
\hline
\end{tabular}

OLS estimates. Robust standard errors in parentheses; ***, **, * indicate significance at 1-, 5-, and 10-percent level, respectively.

Column (1) of Table 1 contains coefficient estimates for a specification of the wage equation, in which the log of monthly net earnings is regressed on a cubic experience term, a quadratic tenure term, years of schooling, a dummy taking the value 1 if the individual worked in East Germany, a dummy for public sector employment, and on dummies for 2-digit occupations. As one would expect, experience and tenure wage profiles are positive but concave. The return to one additional year of education is around 5 percent; East Germans earn around 30 percent less than West Germans, and employees in the public sector earn around 9 percent less than employees in the private sector.

In Column (2), we augment the Mincer wage equation from Column (1) with the survey measure of an individual's willingness to take risks, in order to see whether individuals with higher willingness to take risks earn higher wages. The statistically significant positive effect of willingness to take risks on the level of wages might reflect the fact that more risk tolerant individuals accept riskier jobs within the 2-digit occupation cluster, for which they receive a risk premium. The coefficient estimate does not, however, reflect a compensating wage differential on the 2-digit occupation level. This would be captured by the occupation fixed effects. Rather it can be viewed as reflecting the compensation for an individual's productive trait that is captured by the measure of willingness to take risks. Without a measure of the riskiness of an individual's jobs, one cannot unambiguously ascribe this wage premium to a compensating wage differential. In that sense, this approach is complementary to the findings by Hartog et al. (2003). 
Table 2

Earnings Risk and Average Individual Risk Attitudes

\begin{tabular}{|c|c|c|c|c|}
\hline & 2-digit ISCO & Classification & 3-digit ISCO & Classification \\
\hline & (1) & (2) & (3) & (4) \\
\hline \multirow[t]{2}{*}{ Mean Risk Attitude by Occupation } & $0.051 * *$ & $0.047 * *$ & $0.035^{* *}$ & $0.033 * *$ \\
\hline & $(0.019)$ & $(0.018)$ & $(0.014)$ & $(0.014)$ \\
\hline \multirow[t]{2}{*}{ Constant } & 0.044 & 0.065 & 0.113 & $0.126^{*}$ \\
\hline & $(0.095)$ & $(0.093)$ & $(0.075)$ & $(0.073)$ \\
\hline Observations & 28 & 28 & 102 & 102 \\
\hline R-squared & 0.22 & 0.20 & 0.06 & 0.05 \\
\hline
\end{tabular}

OLS estimates. Robust standard errors, allowing for clustering at the 2-digit occupation level, in parentheses; $* * *, * *, *$ indicate significance at 1-, 5-, and 10-percent level, respectively. Dependent Variable is standard deviation of wage residuals on 2-digit occupation level in specifications in columns (1)-(2), and on 3-digit occupation level in specifications in columns (3)-(4).

Columns (3) and (4) report estimates of the same specifications as in Columns (1) and (2), but on the 3-digit level of occupations rather than on the 2-digit level. All results are qualitatively and quantitatively virtually the same as in the baseline specification of Column (1). ${ }^{12}$

We construct our earnings risk measures for 2-digit and 3-digit occupation categories, using the residuals from Columns (2) and (4), respectively. There are sizable differences in the amount of earnings risks across occupations. The values of our earnings risk measure range from around 0.2 to 0.8 with a mode of around 0.35 and a mean of about 0.4 . We use the specifications that control for risk attitudes in order to rule out a potential source of spurious correlation. In particular, later we show that occupations with higher earnings also have higher earnings variance. Thus, without controlling for risk attitudes when calculating the earnings variance, the main result, a positive correlation between earnings variance and willingness to take risks, could be driven mechanically by a correlation between willingness to take risks and the level of earnings. However, the main results presented below are not sensitive to using the alternative specifications from Columns (1) and (3) to compute earnings risk. ${ }^{13}$

\section{Risk Sorting and Occupational Earnings Variability}

The key question addressed in our analysis is whether individuals who express a low willingness to take risks are employed in occupations that exhibit lower earnings risk. To investigate this issue, we proceed in two steps. First we investigate whether a correlation between

\footnotetext{
${ }^{12}$ We also estimated both specifications with a measure of log hourly wages instead of monthly wages as the dependent variable. Again, the results are practically identical, qualitatively as well as quantitatively. Hourly wages are calculated based on self-reported information about regular hours worked per week, including paid overtime, however. This measure is more noisy than monthly earnings since hours are measured with error, and so we concentrate attention to monthly wages as our preferred variable of interest. Detailed results are available upon request.

${ }^{13}$ For a first indication of whether the positive coefficient of risk attitudes in the wage regression reflects a productive trait that can be separated from risk sorting, we performed unreported regressions of an extended specification of the wage regressions of Table 1, with additional controls for earnings risk in a given occupation and an interaction between earnings risk and individual risk attitudes. In these regressions, we find some evidence for a small direct effect of earnings risk and risk attitudes on the level of earnings, but a significant positive effect of the interaction term in all specifications except for that in column (4). These findings suggest that individuals who are willing to take risks and who work in occupations with higher cross-sectional earnings risk earn higher wages.
} 
occupation-specific earnings risk and willingness to take risk exists on the aggregate level. This would be the case if there was occupational sorting based on risk attitudes. Since this approach does not allow us to take individual specific factors into account, in a second step, we adopt a more disaggregate view and regress occupational earnings risk on individual characteristics of workers who are sorted into their particular occupations. Note that we implicitly assume that earnings risk is separable from other sources of occupation-specific risks. In this respect, our paper complements earlier contributions in the literature that concentrated on other determinants of occupational choice.

The results of the first step of this analysis are summarized in Table 2 . The table presents the results of regressions with the 2-digit occupation earnings risk as the dependent variable, where the earnings risk used in a particular column is based on the residuals from the Mincer wage regression in the respective column of Table 1 . The key regressor of interest is the average willingness to take risks of individuals employed in the respective occupation. The observations are weighted by the size of the particular occupation cell.

The results show that higher average willingness to take risks in a particular occupation is associated with higher earnings risk in that occupation. Such a positive relationship is also found for all our alternative measures of earnings risk derived from the other three specifications of the wage equation in Table 1 . The results are strikingly robust across all specifications: the higher the average willingness to take risks expressed by individuals of a given occupation, the higher is the earnings risk in that occupation. The respective estimated coefficients are always highly significant and positive. ${ }^{14}$ Moreover, the estimates are somewhat smaller when using information on the 3-digit occupation level rather than on the 2-digit level.

Table 3 shows the results from OLS regressions of our measures of occupational earnings risk on individual risk attitudes, rather than on occupation-specific averages. The table reports the results for one of our earnings risk measures only, namely the measure that we constructed based on the residuals of the Mincer wage regression specified in column (2) of Table 1. ${ }^{15}$ The main result of the analysis is already evident from the coefficient estimate of the general risk attitude in Column (1): the more willing to take risks a person is in general, the more likely it is that this person works in an occupation that exhibits higher earnings risk.

In order to see whether this result is robust to including controls for observable individual and job-specific characteristics, we add potential experience, tenure, years of education, marital status and cohabitation, body height, a dummy for living in East Germany, and a public sector dummy as explanatory variables in the specification in Column (2). The key result is that the coefficient estimate for willingness to take risks is unaffected. The other coefficient estimates indicate that highly educated individuals are more prevalent in occupations with higher earnings risk; taller and more experienced workers are also significantly more prevalent ${ }^{16}$, but the coefficient estimates are small compared to the coefficients on risk. East German workers are less likely to be sorted into occupations with high earnings risks, holding constant individual risk attitudes. Moreover, being employed in the public sector is associated with lower occupation-specific earnings risk. This might imply that occupation-specific earnings risk is lower the larger the share of public sector employment. The choice between working in the public versus the private sector adds

\footnotetext{
${ }^{14}$ The coefficients obtained using monthly earnings are larger than those obtained with hourly wages, which might reflect measurement error in reported hours.

15 Results for all other risk measures based on the different specifications in Table 1 are very similar and available upon request. The results are also robust - but somewhat smaller - when the risk measure is based on hourly wages rather than on monthly earnings.

16 Dohmen et al. (2005) show that height is positively related to willingness to take risks.
} 
Table 3

Earnings Risk and Individual Risk Attitudes

Dependent Variable: Standard Deviation of Occupational Wage Residuals

\begin{tabular}{|c|c|c|c|}
\hline & (1) & (2) & (3) \\
\hline General Risk Attitude & $\begin{array}{l}0.001 * * * \\
(0.0004)\end{array}$ & $\begin{array}{l}0.001 * * * \\
(0.0003)\end{array}$ & $\begin{array}{c}0.001 * * \\
(0.0003)\end{array}$ \\
\hline Experience $* 100$ & & $\begin{array}{c}0.020 \\
(0.014)\end{array}$ & $\begin{array}{c}0.009 \\
(0.012)\end{array}$ \\
\hline Tenure $* 100$ & & $\begin{array}{c}0.005 \\
(0.015)\end{array}$ & $\begin{array}{c}-0.009 \\
(0.015)\end{array}$ \\
\hline Years of Education & & $\begin{array}{l}0.004^{* * *} \\
(0.001)\end{array}$ & $\begin{array}{l}0.002^{* * *} \\
(0.001)\end{array}$ \\
\hline Married living together & & $\begin{array}{c}-0.001 \\
(0.002)\end{array}$ & $\begin{array}{c}-0.002 \\
(0.002)\end{array}$ \\
\hline Body height $* 10$ & & $\begin{array}{c}0.002 * \\
(0.001)\end{array}$ & $\begin{array}{c}0.001 \\
(0.001)\end{array}$ \\
\hline East Germany & & $\begin{array}{c}-0.003 \\
(0.001)\end{array}$ & $\begin{array}{c}0.002 \\
(0.002)\end{array}$ \\
\hline Public Sector Employment & & $\begin{array}{c}-0.004 \\
(0.007)\end{array}$ & $\begin{array}{c}-0.002 \\
(0.007)\end{array}$ \\
\hline Log Monthly Income & & & $\begin{array}{l}0.014^{* *} \\
(0.006)\end{array}$ \\
\hline Constant & $\begin{array}{l}0.299 * * * \\
(0.001)\end{array}$ & $\begin{array}{l}0.219^{* * *} \\
(0.013)\end{array}$ & $\begin{array}{c}0.143^{* *} \\
(0.058)\end{array}$ \\
\hline Observations & 4094 & 3985 & 3605 \\
\hline R-squared & 0.004 & 0.11 & 0.13 \\
\hline
\end{tabular}

OLS estimates. Robust standard errors of coefficient estimates, allowing for clustering at the 2-digit occupation level, in parentheses; $* * *, * *, *$ indicate significance at 1-, 5-, and 10-percent level, respectively. Dependent Variable is the standard deviation of occupational wage residuals, obtained from wage regressions of specification (2) in Table 1, on 2digit ISCO Classification level.

another dimension to occupational sorting if individuals make a joint decision concerning their occupation and whether to work in the public or the private sector.

In Column (3), we include log individual monthly earnings as an additional control. Individuals' actual earnings might capture some unobserved characteristics that are also related to occupational choice and willingness to take risk. Irrespective of such a relation, we expect earnings to have a positive effect due to the fact that earnings are on average higher in occupations with greater earnings risk. ${ }^{17}$ Although we are aware of the potential endogeneity problem with respect to including monthly earnings as a control variable, we still think that the potential importance of this variable justifies reporting the results. Not surprisingly, the inclusion of individual earnings takes away some explanatory power from the other controls, and reveals a positive and significant coefficient of the earnings risk in a given occupation. The main coefficient of interest, however, remains highly significant.

These results are consistent with a costly, instantaneous occupational sorting process. In reality, however, occupational sorting is a time-consuming process, and decisions during this process have persistent effects. At the beginning of labor market career individuals are typically not fully informed about earnings potential or the quality of their match, or even about work

\footnotetext{
17 This correlation is consistent with a risk premium, but could also be driven by a mechanical effect, given that positively valued random variables, like incomes, tend to be characterized by a positive correlation between mean and variance.
} 
Table 4

Earnings Risk and Individual Risk Attitudes

Dependent Variable: Standard Deviation of Occupational Wage Residuals

\begin{tabular}{lccc}
\hline & $(1)$ & $(2)$ & $(3)$ \\
\cline { 2 - 4 } & Public and Private & Public & Private \\
\hline General Risk Attitude & $0.001^{* *}$ & -0.00009 & $0.001^{* * *}$ \\
Experience *100 & $(0.000)$ & $(0.001)$ & $(0.0003)$ \\
& 0.006 & 0.024 & 0.015 \\
Tenure *100 & $(0.011)$ & $(0.039)$ & $(0.011)$ \\
& -0.024 & -0.046 & -0.020 \\
Years of Education & $(0.015)$ & $(0.042)$ & $(0.012)$ \\
& $0.004^{* * *}$ & $0.005^{* *}$ & $0.003^{* *}$ \\
Married living together & $(0.001)$ & $(0.002)$ & $(0.002)$ \\
Body height*10 & -0.005 & 0.003 & $-0.007^{* *}$ \\
East Germany & $(0.003)$ & $(0.004)$ & $(0.003)$ \\
Public Sector Employment & 0.001 & 0.003 & 0.001 \\
& $(0.001)$ & $(0.003)$ & $(0.001)$ \\
Log Monthly Income & 0.002 & 0.012 & -0.001 \\
Constant & $(0.003)$ & $(0.008)$ & $(0.003)$ \\
Observations & $-0.063^{* * *}$ & & $(0.067)$ \\
R-squared & $(0.011)$ & & $(0.167)$ \\
\hline
\end{tabular}

OLS estimates. Robust standard errors of coefficient estimates, allowing for clustering at the 2-digit occupation level, in parentheses; $* * *, * *, *$ indicate significance at 1-, 5-, and 10-percent level, respectively. Dependent Variable is the standard deviation of occupational wage residuals as obtained from wage regressions (on the 2-digit ISCO Classification level) analogous to specification (2) in Table 1 for the respective sample.

conditions when choosing a particular occupation. Hence, it might take time until the process of occupational sorting is completed. ${ }^{18}$ Job shopping would imply lower estimates of the correlation between earnings risk and individual risk attitudes for young cohorts. Likewise, endogenous risk attitudes would imply a weaker relationship between risk attitudes and earnings risk within a chosen occupation. ${ }^{19}$ In order to shed light on the question whether a lengthy sorting process, learning, or problems of reversed causality contaminate our results, we performed our analysis separately for sub-samples with different levels of labor market experience (see Dohmen et al., 2006). We find that the strongest positive and significant correlation between risk attitudes and cross-sectional earnings risk for workers with 15 to 28 years of labor market experience (which corresponds to the second and third quartile of the experience distribution), while we find only a weak positive, but statistically not significant relationship for individuals in the bottom quartile (less than 15 years of potential experience). These findings suggest that occupational sorting according to risk attitudes and earnings risk is weak for labor market entrants. But after having

\footnotetext{
${ }^{18}$ Risk taking behavior might also be non-stationary. For example, individuals might accept higher earnings risk early in their career, despite identical risk preferences, see e.g. Jovanovic and Nyarko (1997).

19 This is true unless individuals respond to higher than expected earnings risk by adjusting their attitudes and perceptions to avoid disutility from cognitive dissonance (Festinger, 1957).
} 
collected enough information about their talents and the labor market, individuals seem to sort themselves into occupations (and sectors) that exhibit earnings risk, which they deem adequate given their individual willingness to take risks. We also find no significant positive relationship for those who have spent the longest time on the labor market. A reverse causality explanation therefore seems less adequate given that the correlation appears to be hump-shaped and becomes weaker (and eventually disappears) for longer labor market experience.

In order to assess whether our results on occupational sorting according to risk attitudes are robust, we estimate our econometric models separately for employees in the private and in the public sector. The choice between becoming self-employed or working in the private vs. the public sector represents another dimension that might be relevant for risk sorting and that affect earnings risk. Risk attitudes have already been shown to have an impact on the decision to become self-employed in the studies of Ekelund et al. (2005), Dohmen et al. (2005) and Caliendo et al. (2006). Hence, we concentrate on the decision between working as a public employee versus working in the private sector. We treat occupational and sectoral choice as a joint decision and estimate a Mincer wage equation as specified in Column (2) of Table 1 with dummies for each of the 50 2-digit occupation-sector cells in our data. ${ }^{20}$ Based on the residuals from this regression we construct our occupation-specific earnings risk measure. As expected, earnings risk is higher in private sector occupations than in public sector occupations. This measure is then related to risk attitudes. The first column of Table 4 reports regression results, using the same specification as in column (6) of Table 3. The main result is the same as in Table 3: higher willingness to take risks makes an individual more likely to work in occupations with higher earnings variability. The results also make clear that working in the public sector implies a significantly lower earnings risk than working in the private sector. Additionally, individuals living together with a spouse are significantly more likely to work in an occupation with lower earnings variability. Similar results hold for individuals with less education and longer tenure. Note also that the coefficient estimate for individual willingness to take risk is larger if we do not control for earnings.

The estimates in Columns (2) and (3) are based on separate estimations for public and private sector employment, respectively. In other words, we check whether individuals who have decided to work in a particular sector sort into occupations with different earnings risk within that sector based on their risk attitude. Interestingly the results in Column (2) suggest that neither risk attitudes nor education play a role for occupational sorting with different earnings risk within the public sector. This could reflect the fact that earnings risks are generally small in all occupations within the public sector. In contrast, the estimates in Column (3) reveal that these attributes have a significant impact on occupational choice within the private sector. These results indicate that risk sorting apparently affects both occupational sorting as well as the choice to work in the private or public sector.

\section{Conclusion}

This paper provides evidence that individuals are sorted according to their risk attitudes into occupations that differ with regard to cross-sectional earnings risk. We measure risk attitudes by selfreported, behaviorally relevant statements about risk attitudes of individuals, and construct an earnings risk measure that reflects the cross-sectional variation in wages that is not explained by

\footnotetext{
${ }^{20}$ Hence, we treated a 2-digit occupation in the private sector as a different category than the same occupation in the public sector. We end up with 50 non-empty cells since we do not have observations for all occupation-sector cells.
} 
observable heterogeneity in human capital investments. The more willing individuals are to take risks according to the survey question, the more likely they are to end up working in an occupation with high earnings risk. As a result of this sorting process, prime-age men employed in a particular sector are on average more willing to take risks the higher is the earnings risk in that occupation.

These results hold regardless whether occupations are defined on the 2-digit level or on the 3digit level. Since the occupational distribution of earnings is reasonably stable over time in Germany, and since it can be taken as given from an individual's perspective, the results strongly suggest that earnings risk is a relevant sorting criterion when individuals with heterogeneous risk attitudes make their occupational choice.

Showing the relevance of cross-sectional earnings risk does not mean, of course, that other factors such as unemployment risk, fatality risk, various abilities, or attitudes are irrelevant for occupational sorting. A more holistic investigation of occupational choice, which takes several relevant dimensions of risk as well as other determinants into account, is desirable but beyond the scope of this paper.

\section{Acknowledgements}

The authors are grateful for comments by René Fahr, Joop Hartog, two anonymous referees, the participants in the IZA/University of Amsterdam workshop on Schooling and Risk, and conferences of the Verein für Socialpolitik, ESPE 2006, and EALE 2006.

\section{References}

Barsky, R.B., Juster, T.F., Kimball, M.S., Shapiro, M.D., 1997. Preference Parameters and Individual Heterogeneity: An Experimental Approach in the Health and Retirement Study. Quarterly Journal of Economics 112 (2), 537-579.

Brown, C., 1980. Equalizing Differences in the Labor Market. Quarterly Journal of Economics 94 (1), $113-134$.

Caliendo, M., Fossen, F.M., Kritikos, A.S., 2006. Risk Attitudes of Nascent Entrepreneurs: New Evidence from an Experimentally Validated Survey. IZA Discussion Paper, No. 2168.

Cramer, J.S., Hartog, J., Jonker, N., van Praag, C.M., 2002. Low risk aversion encourages the choice for entrepreneurship: an empirical test of a truism. Journal of Economic Behavior \& Organization 48 (1), 29-36.

DeLeire, T., Levy, H., 2004. Worker Sorting and the Risk of Death on the Job. Journal of Labor Economics 19 (4), $837-878$.

Dohmen, T., Falk, A., 2006. Performance Pay and Multi-dimensional Sorting — Productivity, Preferences and Gender. IZA Discussion Paper, No. 2001.

Dohmen, T., Falk, A., Huffman, D., Sunde, U., Schupp, J., Wagner, G.G., 2005. Individual Risk Attitudes: New Evidence From a Large, Representative, Experimentally-Validated Survey. IZA Discussion Paper, No. 1730.

Dohmen, T., Falk, A., Huffman, D., Sunde, U., 2006. Cross-sectional Earnings Risk and Occupational Sorting: The Role of Risk Attitudes. IZA Discussion Paper, No. 1930.

Ekelund, J., Johansson, E., Järvelin, M.-R., Lichtermann, D., 2005. Self-Employment and Risk Aversion — Evidence from Psychological Test Data. Labour Economics 12 (5), 649-659.

Festinger, L., 1957. A Theory of Cognitive Dissonance, 1st ed. Stanford University Press, Stanford, CA.

Fitzenberger, B., Kunze, A., 2005. Vocational Training and Gender: Wages and Occupational Mobility among Young Workers. Oxford Review of Economic Policy 21 (3), 392-415.

Harrison, G., Lau, M.I., Rutstrom, E.E., 2005. Estimating Risk Attitudes in Denmark: A Field Experiment. mimeo, Unversity of Central Florida.

Hartog, J., Plug, E., Diaz-Serrano, L., Vieira, J., 2003. Risk Compensation in Wages - A Replication. Empirical Economics 28 (3), 639-647.

Hwang, H.-S., Reed, W.R., Hubbard, C., 1992. Compensating Wage Differentials and Unobserved Productivity. Journal of Political Economy 100 (4), 835-858.

Jovanovic, B., Nyarko, Y., 1997. Stepping-Stone Mobility. Carnegie-Rochester Conference Series on Public Policy 46, $289-325$. 
McGoldrick, K., 1995. Do Women Receive Compensating Wages For Earnings Risk? Southern Economic Journal 62 (1), $210-222$.

Mincer, J., 1974. Schooling, Experience, and Earnings. Columbia University Press, New York.

Moore, M.J., 1995. Unions, Employment Risks, and Market Provision of Employment Risk Differentials. Journal of Risk and Uncertainty 10 (1), 57-70.

Murphy, K.M., Topel, R., 1987. Unemployment, Risk and Earnings: Testing for Equalizing Differences in the Labor Market. In: Lang, K., Leonard, J. (Eds.), Unemployment and the Structure of Labor Markets. Basil Blackwell, New York, pp. 103-140.

Rosen, S., 1986. The Theory of Equalizing Differences. In: Ashenfelter, O., Layard, R. (Eds.), Handbook of Labor Economics, pp. 641-692.

Thaler, R., Rosen, S., 1976. The Value of Saving a Life: Evidence from teh Labor Market. In: Terleckyj, N. (Ed.), Household Production and Consumption. Columbia University Press, New York.

Topel, R.H., 1984. Equilibrium Earnings, Turnover, and Unemployment: New Evidence. Journal of Labor Economics 2 (4), 500-522. 